\title{
Multifocal Visual Evoked Potential mfVEP
}

Saly H Elkholy*

Professor of clinical neurophysiology, Cairo University, Egypt

*Corresponding author: Elkholy SH, Professor of clinical neurophysiology, Cairo University, 106 Maadi, Cairo, Egypt, E-mail: elkholysaly@hotmail.com

Received date: January 05, 2015; Accepted date: January 19, 2015; Published date: January 26, 2015

Copyright: (C) 2015 Elkholy SH. This is an open-access article distributed under the terms of the Creative Commons Attribution License, which permits unrestricted use, distribution, and reproduction in any medium, provided the original author and source are credited.

\section{Commentary}

Although the multifocal visual evoked potential (mfVEP) was introduced in 1994 by Baseler, Sutter and colleagues [1], its development has lagged behind the multifocal electroretinogram (mfERG). The large inter subject variability in mfVEP responses has discouraged its use.

There are two main sources of inter-subject variability. First, the position of the calcarine fissure relative to the external landmarks varies among individuals [2]. Second, individuals differ in the way the cortex is folded and how the primary visual area is positioned within these folds $[3,4]$.

If inter-subject variability is due to cranio-occipital variations, then the mfVEP responses from the two eyes should be identical. The reason for this is purely anatomical; any point in the visual field projects to the nasal retina of one eye and the temporal retina of the other, but both points project to essentially the same region of striate cortex [5].

The waveform of the localized mfVEP response changes in polarity across the horizontal meridian, which could be explained by the position of the generating cortical dipoles relative to the location of the recording electrodes [6]. With bipolar recording, the responses for stimulation of the upper and lower visual fields were reversed in polarity as expected from the anatomy of the visual pathways $[1,7]$.

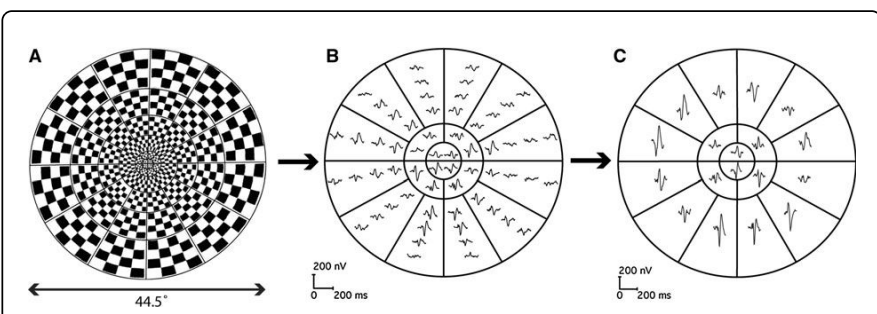

Figure 1: (a) The 60 element mfVEP array stimulus viewed by the patient (b) The 60 response waveforms from a control subject (c) The responses were then summed into 18 responses for better signal to noise ratio in the array shown. The array with 18 summed response waveforms [13]

Compared with most electrophysiological tests of visual function, the mfVEP has the advantage that it produces a topographical measure of damage [8]. It does not seem to have a learning curve [9], and it has a high level of patient acceptance [10]. It has been shown to be $95 \%$ to $97 \%$ sensitive for glaucomatous scotoma detection in clinical trials. In contrast with hemifield visual loss (Humphrey visual field-HVF) testing, the objective perimetry provided by mfVEP is less affected by patient performance or learning curve [11]. It can be used for ruling out nonorganic visual loss, diagnosing and observing patients with optic neuritis and multiple sclerosis, and observing disease progression
[12]. The technique evaluates the pathway from the retinal receptors to the occipital cortex and assesses the visual field out to $30^{\circ}$ using a multifocal pattern VEP stimulus, with multichannel recording. The rapidly alternating checkerboard pattern derives which signal response in the brain came from which location in the field by cross-correlating the signal recorded with the pattern reversal on the screen [8] (Figure $1)$.

The stimulus normally consists of a single cycle of a binary $\mathrm{m}$ sequence. Using a longer $\mathrm{m}$-sequence rather than averaging several shorter ones prevents contamination by higher-order kernels and, thus, provides cleaner separation of the local response contributions [14].

Raw trace data are analyzed with Peak-to-trough amplitudes for each wave within the interval of 60 to $220 \mathrm{~ms}$ are determined and compared among channels for every stimulated segment of the visual field. Amplitude and latency for each field sector of the mfVEP is determined [6]. It is important to monitor the patient's eye position as unsteady fixation can cause diminished responses in the centre of the field [15].

The diagnostic utility of mfVEP is enhanced by combining it with mfERG. Retinal problems could be missed if the diagnosis is based on mfVEP of normal or near normal amplitude, on the other hand in patients with marked delayed mfVEP retinal problem could be confused with optic neuritis particularly with normal appearing fundus [16].

\section{References}

1. Baseler HA, Sutter EE, Klein SA, Carney T (1994) The topography of visual evoked response properties across the visual field. Electroencephalogr Clin Neurophysiol 90: 65-81.

2. Steinmetz H, Fürst G, Meyer BU (1989) Craniocerebral topography within the international 10-20 system. Electroencephalogr Clin Neurophysiol 72: 499-506.

3. Brindley GS (1972) The variability of the human striate cortex. J Physiol 225: 1P-3P.

4. Stensaas SS, Eddington DK, Dobelle WH (1974) The topography and variability of the primary visual cortex in man. J Neurosurg 40: 747-755.

5. Hood DC, Zhang X, Greenstein VC, Kangovi S, Odel JG, et al. (2000) An interocular comparison of the multifocal VEP: a possible technique for detecting local damage to the optic nerve. Invest Ophthalmol Vis Sci 41: 1580-1587.

6. Klistorner A, Graham SL (2000) Objective perimetry in glaucoma. Ophthalmology 107: 2283-2299.

7. Klistorner AI, Graham SL, Grigg JR, Billson FA (1998) Multifocal topographic visual evoked potential: improving objective detection of local visual field defects. Invest Ophthalmol Vis Sci 39: 937-950.

8. Punjabi OS, Lin SC, Stamper RL (2006) Advances in Mapping the Glaucomatous Visual Field: From Confrontation to Multifocal Visual Evoked Potentials. The Internet Journal of Ophthalmology and Visual Science 4. 
9. Graham SL, Klistorner A, Balachandran C, Goldberg I (2003 Intrasubject variability of mulifocal VEP in normals and glaucoma Invest Ophthalmol Vis Sci 44: 45.

10. Bjerre A, Grigg JR, Parry NR, Henson DB (2004) Test-retest variability of multifocal visual evoked potential and SITA standard perimetry in glaucoma. Invest Ophthalmol Vis Sci 45: 4035-4040.

11. Goldberg I, Graham SL, Klistorner AI (2002) Multifocal objective perimetry in the detection of glaucomatous field loss. Am J Ophthalmol 133: 29-39.

12. Hood DC, Odel JG, Winn BJ (2003) The multifocal visual evoked potential. J Neuroophthalmol 23: 279-289.
13. Wolff BE, Bearse MA Jr, Schneck ME, Barez S, Adams AJ (2010) Multifocal VEP (mfVEP) reveals abnormal neuronal delays in diabetes. Doc Ophthalmol 121: 189-196.

14. Sutter EE (2010) Noninvasive Testing Methods: Multifocal Electrophysiology.

15. Winn BJ, Shin E, Odel JG, Greenstein VC, Hood DC (2005) Interpreting the multifocal visual evoked potential: the effects of refractive errors, cataracts, and fixation errors. Br J Ophthalmol 89: 340-344.

16. Chen JY, Hood DC, Odel JG, Behrens MM (2006) The effects of retinal abnormalities on the multifocal visual evoked potential. Invest Ophthalmol Vis Sci 47: 4378-4385. 